\title{
PEMBAHARUAN PENDIDIKAN ISLAM ALA HARUN NASUTION (Sebuah Refleksi Akan Kerinduan "Keemasan Islam")
}

\author{
Sukma Umbara Tirta Firdaus \\ Universitas Madura Pamekasan \\ Email: sukma1085̄gmail.com
}

\begin{abstract}
Abstrak:
Saat ini, bila kita membicarakan tentang kejayaan Islam masa lalu, lebih-lebih di bidang ilmu pengetahuan, memberikan rasa pilu yang mendalam. Bagaimana tidak, kenyataan yang terjadi sekarang, Islam yang dulu merupakan kaum paling pintar di dunia, kini hanya menjadi penonton dan objek dari perkembangan Ilmu Pengetahuan dan Teknologi yang dihasilkan kaum Barat. Dulu, Islam-lah yang mengajari mereka, namun kenapa sekarang justru mereka yang memegang kendali peradaban di era millenium ini. Harun Nasution mengungkapkan, fenomena ini karena kesalahan umat Islam sendiri yang tidak mau beranjak untuk bangkit kembali setelah kemundurannya. Umat Islam hanya pasrah dan nrimo, akal tidak kembali diasah dan dibiarkan tumpul. Islam harus kembali bangkit dengan memerdekakan akal, penganutan teologi yang tepat, menempatkan posisi akal sesuai kebutuhannya di antara wahyu. Harun menegaskan, tiga hal tersebut merupakan pola baru yang harus dikembangkan, terutama dalam pendidikan Islam, agar Islam tidak semakin terpuruk.

Katakunci: Harun Nasution, kemerdekaan akal, pendidikan Islam.
\end{abstract}

Abstract:

Today, when we talk about the glory of Islam in the past, especially in the field of science, gives a deep sense of pain. How not, the fact that is happening now, Islam that was once the most intelligent people in the world, is now only a spectator and object of the development of Science and Technology produced by the West. In the past, Islam was the one who taught them, but why now they are in control of civilization in this millennium time. Harun Nasution reveals, this phenomenon because of the error of Muslims themselves who do not want to move to rise again after its decline. Muslims are just resigned and take it as it comes, reason is not re-sharpened and left blunt. Islam must re-emerge by 
Pembaharuan Pendidikan Islam ala Harun Nasution; Sebuah refleksi akan kerinduan "keemasan islam

liberating reason, proper theology, placing the position of reason according to its needs among revelations. Harun asserted, the triad is a new pattern that must be developed, especially in Islamic education, so that Islam is not getting worse.

Keywords: Harun Nasution, freedom of mind, Islamic education.

\section{Prolog}

Secara garis besar, sejarah Islam dapat dibagi ke dalam tiga periode besar yaitu; klasik, pertengahan dan modern. Periode klasik (650-1250 M) merupakan zaman kemajuan dan dibagi ke dalam dua fase. Pertama, fase ekspansi, integrasi dan puncak kemajuan (650-1000 M). Di zaman inilah daerah Islam meluas melalui Afrika Utara sampai ke Spanyol di Barat, dan melalui Persia sampai ke India di Timur. Daerah-daerah tersebut tunduk kepada Khilafah Islam. Di masa itu pulalah berkembang dan memuncak ilmu pengetahuan, baik dalam bidang agama maupun non-agama (ilmu umum). ${ }^{1}$ Disebut pula saat itu adalah zaman "keemasan Islam", sebab peradaban dunia benar-benar menjadi milik Islam. Kedua, fase disintegrasi (10001250). Pada masa ini keutuhan umat Islam dalam bidang politik mulai pecah. Kekuasaan Khalifah menurun dan akhirnya Bagdad dapat dirampas dan dihancurkan oleh Hulagu Khan ${ }^{2}$ pada 1258 M. Khilafah sebagai lambang kesatuan politik umat Islam runtuh. ${ }^{3}$

Periode pertengahan (1250-1800 M), merupakan perode kemunduran Islam, karena disintergrasi semakin meluas, selain itu karena carut-marutnya politik umat Islam kurang sekali perhatiaannya kepada ilmu pengetahuan. Lambat-laun puncak ilmu pengetahuan Islam yang dibanggakan pada periode sebelumnya mulai runtuh. Hal ini ditandai dengan pemikiranpemikiran ulama yang bersifat dogmatis, didukung pula oleh perbedaanperbedaan pemikiran yang terjadi antara ulama Sunni dengan ulama Syiah. ${ }^{4}$

Selanjutnya, periode Modern (1800 M-sekarang) merupakan zaman awal umat Islam bangkit. Mereka mulai sadar akan keterpurukannya karena ilmu pengetahuan yang telah mereka tinggalkan. Kebangkitan umat Islam ini berawal dari kehancuran tiga kerajaan besar yaitu; Turki Usmani, Safawi di Persia, dan Mughal di India. Ditambah lagi atas berkuasanya Napoleon pada 1798 di Mesir, yang merupakan salah satu dari pusat dunia Islam

\footnotetext{
${ }^{1}$ Harun Nasution, Pembaharuan Dalam Islam; Sejarah Pemikiran dan Gerakan, (Jakarta: Bulan Bintang, 1992), Cet. IX. 13.

${ }^{2}$ Hulagu Khan adalah pimpinan tentara Mongol yang berhasil menahlukkan Bagdad (pusat pemerintahan Khilafah saat itu, yang dipimpin oleh Khalifah al-Musta'sim).

${ }^{3}$ Nasution, Pembaharuan, 13.

${ }^{4}$ Abuddin Nata, Metodologi Studi Islam, (Jakarta: Raja Grafindo Persada, 2014), 376.
} 
Pembaharuan Pendidikan Islam ala Harun Nasution; Sebuah refleksi akan kerinduan "keemasan islam

terpenting. Atas dasar inilah para pemuka-pemuka Islam tersadarkan bahwa Islam dalam keadaan terbelakang dan lemah. ${ }^{5}$ Bermunculanlah para pemikirpemikir Islam dari Mesir sendiri, dan dari daerah-daerah lain, baik yang belajar di Mesir atau di negara Islam lainnya, mengkampanyekan ide-ide pembaruan Islam agar kondisi Islam bisa lebih baik, tidak lagi terpuruk, apalagi sampai mengulang periode kejayaan Islam masa lalu. Salah satu pemikir Islam tersebut adalah Harun Nasution, orang Indonesia yang sempat menetap lama dan bersekolah di Mesir, yang juga mengkampanyekan ide pembaharuan Islam tersebut di tanah airnya, mengingat Indonesia adalah negara dengan penduduk Islam terbesar di dunia.

\section{Biografi Singkat Harun Nasution}

Harun Nasution, adalah mantan Rektor Institut Agama Islam Negeri (IAIN) Syarif Hidayatullah Jakarta selama dua periode (1974-1982). Ia dilahirkan di Pemantang Siantar, Sumatera Utara, pada 23 September 1919, bertepatan pada hari Selasa Legi (Manis). Profesor yang biasa disapa Pak Harun ini merupakan anak dari pasangan Abdul Jabal Ahmad dan Maimunah. Abdul Jabal Ahmad merupakan seorang pedagang dari Mandailing dan juga seorang Qạ̃í (Penghulu) pada masa pemirintahan kolonial Belanda. Ayah Harun juga seorang ulama yang menguasai Kitabkitab Jawa dan Kitab Kuning berbahasa Melayu. Maimunah seorang wanita dari daerah yang sama, yang juga keturunan ulama. Ibu Harun ketiga gadis pernah bermukim di Makkah, mengikuti orang tuanya, dan mengikuti beberapa kegiatan di Masjidil Haram. Dari latar belakang kedua orang tuanya yang keturunan ulama, secara otomatis Harun juga cucu dan anak ulama, maka pendidikan dan pemahaman Agama Islam telah dikenal dan menjadi santapan sehari-hari Harun kecil di rumahnya. ${ }^{6}$

Selain merupakan keturunan dari keluarga yang taat beragama dan terhormat, orang tua Harun juga tergolong orang yang mampu di bidang ekonomi saat itu. Ayahnya adalah pedagang sukses yang memiliki strategi ekonomi handal. Sehingga tidak menjadi persoalan dan kendala bagi Harun di dalam menempuh pendidikan, sebab dari segi biaya sekolah sudah dicukupi oleh orang tuanya. Orang tuanya sangat menginginkan Harun menajadi orang pintar di kemuian hari. Tentunya menjadi ahli di bidang keilmuwan keislaman, sebagai tongkat estafet keluarga ulama dari nenek moyangnya.

\footnotetext{
${ }^{5}$ Ibid., 377.

${ }^{6}$ Abdul Halim, Teologi Islam Rasional; Apreriasi Terhadap Wacana dan Praksis Harun Nasution, (Jakarta: Ciputat Press, 2001), 3.
} 
Pembaharuan Pendidikan Islam ala Harun Nasution; Sebuah refleksi akan kerinduan "keemasan islam

Pendidikan formal pertamanya ditempuh di pendidikan dasar Belanda Hollandsch Inlandsche School (HIS). Ia masuk di sekolah tersebut pada usia tujuh tahun, dengan mempelajari Bahasa Belanda, ilmu pengetahuan umum, serta sistem didikan yang disiplin dan ketat. Dalam jenjang ini ditempuh selama tujuh tahun, hingga usia Harun 14 Tahun. Kemudian melanjutkan pada studi Islam di sekolah tingkat menengah di Moderne Islamietische Kweekschool (MIK) yang ter -letak di Bukit Tinggi. Sekolah ini merupakan sekolah guru menengah pertama swasta modern, dengan Bahasa Belanda sebagai pengan tarnya. Di sekolah inilah mulai terlihat daya kritis Harun terhadap hukum-hukum Islam, yang mana kekritisan tersebut bertolak belakang dengan apa yang dianut oleh kedua orang tuanya dan masyarakat sekitar. Di sekolah ini tidak sampai ia selesaikan, hanya berlangsung tiga tahun, dari seharusnya ditempuh enam tahun.

Atas arahan orang tuanya, ia melanjutkan studinya ke Arab Saudi. Di Arab hanya sebentar saja bersekolah karena tidak kerasan, dan meminta untuk pidah ke Mesir. Ayahnya memberikan izin, sehingga ia pindah sekolah ke Mesir. Di Mesir inilah Harun menem -puh pendidikan hingga tingkat sarjana. Pertama ia tempuh di Fakultas Ushuluddin, Universitas Al-Azhar. Lagi-lagi ia tidak kerasan karena merasa tidak cocok dan kurang puas akan proses pendidikan di sana. Kemudian ia pindah ke Universitas Amerika di Kairo, Mesir, hingga lulus 1952 menyandang gelar Bachler of Arts (BA.) pada bidang ilmu pendidikan dan ilmu sosial. ${ }^{7}$

Setelah lulus dari pendidikan tinggi, Harun sempat bekerja di perusahaan swasta di Mesir, sebelum ia bekerja di Konsulat Indonesia Kairo, Mesir. Di saat menjadi pegawai di Konsulat Indonesia-Kairo inilah, pemuda suku Batak ini menikahi perempuan Mesir bernama Sayedah. Setelah menikah, Harun baru pulang ke Indonesia dengan memboyong istrinya yang asli Mesir tersebut. Tak berselang lama di Indonesia, tepatnya pada 1955 Harun mendapat tugas negara untuk menjadi Sekretaris pada Kedutaan Besar Indonesia di Brussel, Belgia. ${ }^{8}$

Di Tahun 1960-an, situasi politik di negaranya, Indonesia, tengah carut-marut dan tidak stabil. Harun tidak tertarik dan merasa ogah mengurusi kekacauan politik tersebut. Akhirnya ia memilih mengundurkan diri dari karir diplomatiknya dan pulang ke negara Istrinya di Mesir. Di sana Harun kembali menekuni ilmu keislaman di bawah bimbingan seorang ulama fikih terkemuka Abu Zahrah. Saat itulah Harun mendapat tawaran

\footnotetext{
${ }_{8}^{7}$ Nasution, Islam Rasional, (Bandung: Mizan, 1995), 5.

${ }^{8}$ Ibid.
} 
Pembaharuan Pendidikan Islam ala Harun Nasution; Sebuah refleksi akan kerinduan "keemasan islam

untuk melaksanakan studi lanjut di Universitas McGill Montreal, Kanada. Tanpa pikir pajang, Harun langsung mengiyakan tawaran tersebut.

Berangkatlah ia ke Kanada, dan mendapatkan gelar magisternya setelah menulis tesis tentang Pemikiran Negara Islam di Indonesia. Program doktoral langsung ia lanjutkan di tempat yang sama, dan pada 1968 gelar $\mathrm{Ph}$.D. diraihnya setelah disertasinya yang berjudul "Posisi Akal dalam Pemikiran Teologi Muhammad Abduh", berhasil dipertahankannya di depan dewan penguji. Pembahasan disertasi tersebut berangkat dari kekaguman Harun terhadap pembaharu Mesir Muhammad Abduh, ${ }^{9}$ salah satu tokoh yang banyak mempengaruhi pola pemikiran Harun di kemudian hari. Harun Nasution merupakan pencetak sejarah, karena ia merupakan putra Indonesia pertama yang bisa mencapai gelar dokter dari Islamic Studies Universitas McGill Kanada. ${ }^{10}$ Setelah itu baru diikuti generasi berikutnya, dan kini telah puluhan doktor yang satu almamater dengan Harun Nasution di Indonesia.

Dengan bergelar Ph.D, Harun pulang ke Indonesia dan aktif di bidang akademik hingga akhir hayatnya dengan menjadi dosen dan menjadi guru besar (Profesor) di IAIN Syarif Hidayatullah Jakarta. Ia mengajar dan membimbing mahasiswa dari jenjang S1 hingga doktor. Banyak muridmuridnya yang menjadi dosen, bahkan menyandang guru besar yang tersebar di berbagi perguruan tinggi di Indonesia. Keilmuan Harun Nasution terus terwarisi kepada mereka dan kepada mahasiswa-mahasiswanya, termasuk kepada kita semua. Harun Nasution sendiri wafat pada 18 September 1998 di Jakarta.

Semasa aktif menjadi dosen, Harun memfokuskan pemikirannya pada pengembangan pemikiran Islam yang dalam bahasanya ia sebut pembaharuan Islam. Karya-karyanya tidak lepas dari tema tersebut. Tak jarang dari beberapa karyanya (tulisannya) mendapat sorotan bahkan kritikan karena dianggap mengandung kontroversi dan keluar dari kaidah umum. Di antara karya-karyanya adalah Islam Ditinjau Dari Berbagai Aspeknya (1974) dua jilid, Pembaharuan Dalam Islam (1975), Teologi Islam (1977), Filsafat Agama (1978), Filsafat dan Mistik Dalam Islam (1978), Aliran Modern Islam (1980), Akal dan Wahyu Dalam Islam (1981), Mohammad Abduh dan Teologi Muktazilah (1987), Islam Rasional (1989), dan lain-lain. Hingga kini, Buku-buku tersebut menjadi rujukan dalam berbagai matakuliah di STAIN, IAIN, UIN dan perguruan-perguruan tinggi

\footnotetext{
${ }^{9}$ Muhammad Abduh lahir di Mesir 1849 dan meninggal di negara yang sama 11 Juli 1905, pada usia 56 tahun. Ia adalah seorang pemikir dari Mesir yang mendunia, salah satu tokoh penggagas gerakan modernisme Islam.

${ }^{10}$ M. Rasjidi dalam Nasution, Teologi Islam; Aliran-aliran Sejarah Analisa Perbandingan, (Jakarta: UI-Press, 1986), Cet. V, vii.
} 
Islam lainnya di seluruh Indonesia. Bahkan ada beberapa yang menjadi buku wajib, baik bagi dosen maupun mahasiswa.

Baginya, sebuah kontroversi yang timbul dalam rangka melakukan sebuah perubahan ke arah yang lebih baik merupakan hal yang wajar, lumrah dan biasa. Karena itu, meski karyanya mendapat sorotan publik, terutama dari kalangan akademis lainnya, ia tidak berhenti untuk menerbitkan karyakarya berikutnya. Paling tidak untuk menunjukkan kepada publik tentang kekonsitenan pemikiran-nya. Atas kokonsistenannya itu ia dipercaya menjabat Rektor IAIN Syarif Hidayatullah Jakarta dari 1974 hingga 1982 (dua periode). Ia juga memelopori berdirinya pascasarjana untuk studi Islam di kampus tersebut. Ia juga pernah menjabat sebagai Dekan Fakultas Pascasarjana IAIN di kampus yang sama. ${ }^{11}$

\section{Pembaharuan Islam}

Pembaharuan Islam dapat dipahami sebagai upaya dalam menyesuaikan pemahaman keagamaan Islam dengan perkembangan jaman terkini sebagai akibat dari kemajuan Ilmu Pengetahuan dan Teknologi (Iptek) modern. ${ }^{12}$ Akan tetapi pembaharuan Islam yang dimaksud ini bukan lantas merubah, mengurangai atau menambahkan teks dalam al-Quran dan al-Hadis, melainkan hanya merubah dan menyesuaikan paham atas keduanya sesuai dengan perkembangan baru yang ditimbulkan kemajuan Iptek tersebut. Hal ini dilakukan karena sebagus apapun paham-paham yang dihasilkan oleh para ulama atau pemikir terdahulu tetap ditemukan kekurangan dan selalu dipengaruhi oleh kecenderungan ilmu pengetahuan, situasi sosial, kebudayaan, dan lain sebagainya. Paham tersebut mungkin masih banyak yang relevan dan masih dapat digunakan, tetapi juga banyak yang sudah tidak sesuai lagi dengan kekinian. ${ }^{13}$

Selain itu, pembaharuan Islam dapat pula diartikan mengubah keadaan umat agar mengikuti ajaran yang terdapat di dalam al-Quran dan alHadis. Ini penting untuk dilakukan, karena telah ditemukan kesenjangan dalam kehidupan umat Muslim dari apa yang diisyratkan al-Quran dan alHadis, dengan kenyataan yang terjadi di masyarakat. Semisal, al-Quran mendorong umat agar menguasai pengetahuan modern serta teknologi secara seimbang, hidup bersatu rukun dan damai, bersikap dinamis, kreatif, inovatif, demokratis, terbuka, menghargai orang lain, menghargai waktu, mencintai kebersihan dan lain-lain. Namun pada kenyataannya, umat Islam menunjukkan keadaan yang berbeda. Sebagian besar umat Islam hanya

\footnotetext{
${ }^{11}$ Nasution, Islam, 6.

${ }^{12}$ Nasution, Pembaharuan, 11.

${ }^{13}$ Nata, Metodologi, 378.
} 
Pembaharuan Pendidikan Islam ala Harun Nasution; Sebuah refleksi akan kerinduan "keemasan islam

menguasai pengetahuan agama sedangkan pengetahuan umum (modern) tidak dikuasainya, hidup dalam keadaan pertentangan dan peperangan, bersikap diktator, kurang menghargai waktu dan lain sebagainya. Keadaan yang demikian merupakan sikap dan pandangan hidup yang tidak sejalan dengan al-Quran dan al-Hadis. Sehingga perlu diper baharui, dengan kembali kepada jalan yang diisyaratkan dua sumber ajaran Islam tersebut. Maka, pembaharuan Islam mengandung pema-haman mengembalikan sikap dan pandangan hidup umat Islam agar searah dan senafas dengan al-Quran dan al-Hadis. ${ }^{14}$

Kenapa memakai kata "pembaharuan", tentunya kata tersebut memiliki makna tersendiri. Sebagaimana diuraikan pada pendahuluan tulisan ini, hemat penulis, kata "baru" itu tidak berdiri sendiri, pasti munculnya kata "baru" karena didahului sesuatu yang sebelumnya pernah ada atau terjadi, yaitu kata "lama". Beda bila sebelumnya belum pernah ada sesuatu atau kejadian, sehingga kata yang muncul saat ini adalah "penciptaan" bukan "pembaharuan". Berabad-abad Islam hadir di dunia ini. Banyak kejadian-kejadian yang mengitarinya, baik Islam sebagai obyek dan Islam sebagai Subyeknya. Nah, di sinilah yang menjadi titik singgung penulis dalam artikel ini.

Awal kemunculannya (zaman Rasulullah Saw), Islam menjadi objek gunjingan, fitnah, pelemahan, dan semacamnya, oleh umat lain. Setelah itu, ketika Islam berani terbuka dengan membuat peradaban di Madinah, posisi Islam lambat-laun berubah dari objek menjadi subjek, hingga terus meningkat Islamisasi ini ke masa Khulafaur Rasyidin dan sesudahnya. Kemajuan Islam tidak hanya dalam bidang aqidah, namun juga dalam peradaban lainnya seperti kebudayaan, pemerintahan, bahkan dalam bidang Iptek. Puncaknya pada masa Dinasti Abbasiyah, Islam menjadi kiblat Iptek dunia. Semua negara Barat belajar kepada Islam. Saat itu Islam benar-benar mencapai puncak, menjadi subjek tunggal kemajuan.

Namun, setelah itu Islam kembali menjadi objek dan tepuruk, di bawah dekte Barat, khususnya dalam perkembangan Iptek. Harun Nasution menyimpulkan, setelah Islam terpuruk, menjadi kehilangan gairah dan semangatnya untuk bangkit kembali. Bukan semangat kejayaan Islam yang berkembang setelah itu, bahkan hingga sekarang, namun semangat menerima apapun yang terjadi karena dipercaya itulah ketentuan Allah Swt yang harus diterima. Semangat tradisional bukan semangat modern yang selalu mengawal kemajuan dan perkembangan zaman. Maka, semangat itulah yang perlu diper-baharui oleh Islam, menghilangan pemahaman

\footnotetext{
${ }^{14}$ Ibid., 379.
} 
tradisional dirubah menjadi pemahaman baru dan modern untuk kembali merebut kejayaan Islam. Dengan paradigma demikian, harapan untuk melepaskan umat Islam dari suasana kemunduran saat ini dan selanjutnya umat Islam hijrah (beranjak) kepada kemajuan akan nyata. ${ }^{15}$

Setelah kembali ke Indonesia dan menjadi intelektual muslim, Harun getol mewacanakan pembaharuan Islam. Dalam bukunya "Pembaharuan Dalam Islam; Sejarah Pemikiran dan Gerakan", muncul ide-ide pembaharuan dengan maksud mengembalikan sikap dan pandangan hidup umat Islam agar sesuai dengan al-Quran dan al-Hadis. Ia mencontohkan seperti apa yang dilakukan Muhammad Abduh, yang mengemukakan ide-ide pambaharunya antara lain dengan cara menghilangkan bid'ah yang terdapat dalam ajaran Islam, kembali kepada ajaran Islam yang sebenarnya, dibukanya kembali pintu ijtihad, menghargai pendapat akal dan menghilangkan sikap dualisme dalam bidang pendidikan. ${ }^{16}$ Harun juga mencontohkan salah seorang tokoh pembaharu Islam di India, Sayyid Ahmad Khan ${ }^{17}$, dimana teori Ahmad Khan mengatakan untuk mencapai kemajuan perlu meninggalkan paham teologi Jabariah (fatalism) ${ }^{18}$ diganti dengan paham Teologi Qadariah (free will dan free act), ${ }^{19}$ perlu percaya bahwa hukum alam dengan wahyu yang ada dalam al-Quran tidak bertentangan, karena kedua-duanya berasal dari Tuhan dan perlu dihilangkan paham taklid ${ }^{20}$ diganti dengan paham ijtihä ${ }^{21} .^{22}$

\footnotetext{
${ }^{15}$ Nasution, Pembaharuan, 11.

${ }^{16}$ Ibid., 62-67.

${ }^{17}$ Sayyid Ahmad Khan lahir 17 Oktober 1817 dan meninggal 27 Maret 1898 pada usia 80 tahun, merupakan warga negara India yang berprofesi sebagai pendidik dan politikus, dikenal sebagai tokoh reformis dan modernis Islam. Ia memelopori pendidikan modern bagi komunitas Islam India. Salah satu produk dari pendidikan modern di India adalah Zakir Naik, yang saat ini tengah naik daun dan pemikirannya menjadi perhatian dunia.

${ }^{18}$ Harun Nasution mengistilahkan bahwa aliran Jabariah adalah paham yang menyebutkan bahwa segala perbuatan manusia telah ditentukan dari semula oleh qadha dan qadhar Allah. Setiap perbuatan yang dikerjakan manusia tidak berdasarkan kehendak manusia, tetapi diciptakan oleh Allah dan dengan kehendak-Nya. Manusia tidak mempunyai kebebasan dalam berbuat karena tidak memiliki kemampuan. Ada yang mengistilahkan bahwa Jabariyah adalah aliran manusia menjadi wayang dan Allah sebagai dalangnya.

${ }^{19}$ Harun Nasution mengungkapkan aliran Qadariah memahami bahwa manusia mempunyai kekuatan untuk melaksanakan kehendaknya, dan bukan berasal dari pengertian bahwa manusia terpaksa tunduk pada Allah. Segala tindakan manusia tidak diintervensi Allah. Tiaptiap orang adalah pencipta bagi segala perbuatannya, dapat berbuat sesuatu atau meninggalkannya atas kehendaknya sendiri. Memberikan kedudukan yang tinggi kepada akal manusia, untuk memilih mana yang baik dan mana yang buruk. Nasution, Teologi, 33-39.

${ }^{20}$ Taklid adalah mengikuti pendapat orang lain tanpan mengetahui sumber atau alasannya.

${ }^{21}$ Ijitihād adalah sebuah usaha yang sungguh-sungguh, bisa dilakukan oleh siapa saja yang berusaha mencari ilmu untuk memutuskan suatu perkara yang tidak dibahas di alam al-Quran maupun al-Hadis dengan syarat menggunakan akal sehat dan pertimbangan matan. Namun
} 
Beberapa ayat al-Quran yang mengisyaratkan pentingnya akal untuk difungsikan antara lain:

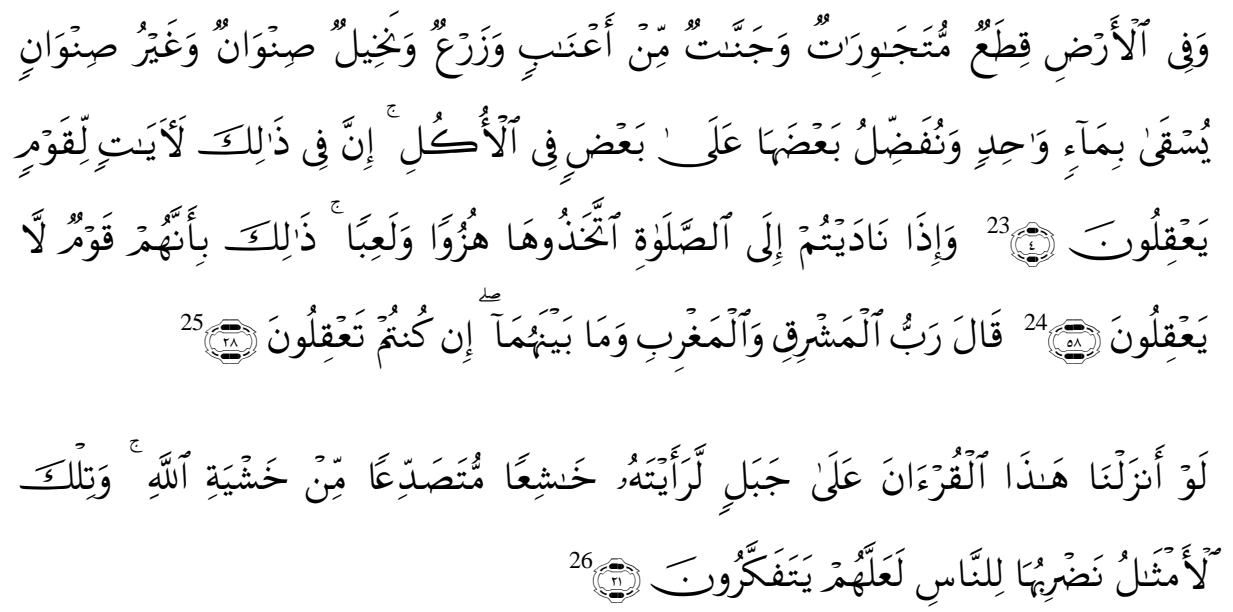

Kepulangan Harun dari Kanada menjadi titik tolak dirinya melangkah ke pemikiran Pembaharuan Islam. Harun mengusik kaum Muslim Indonesia yang sekian lama dilanda kejumudan ${ }^{27}$ berfikir. Dengan gencarnya Harun bersuara tentang pembaharuan Islam, menempatkan dirinya menjadi tokoh

pada perkembangan selanjutnya, diputuskan bahwa ijtihad sebaiknya hanya dilakukan para ahli agama Islam.

${ }^{22}$ Nasution, Pembaharuan, 168-169.

${ }^{23}$ Artinya, "Dan di bumi ini terdapat bagian-bagian yang berdampingan, dan kebun-kebun anggur, tanaman-tanaman dan pohon korma yang bercabang dan yang tidak bercabang, disirami dengan air yang sama. Kami melebihkan sebahagian tanam-tanaman itu atas sebahagian yang lain tentang rasanya. Sesungguhnya pada yang demikian itu terdapat tandatanda (kebesaran Allah) bagi kaum yang menggunakan akal." (QS. Al-Ra'du: 4).

${ }^{24}$ Artinya, "Dan apabila kamu menyeru (mereka) untuk (mengerjakan) sembahyang, mereka menjadikannya buah ejekan dan permainan. Yang demikian itu adalah karena mereka benarbenar kaum yang tidak mau mempergunakan akal." (QS. Al-Māidah: 58). Di ayat ini Allah mengisyaratkan bahwa manusia yang tidak mempergunakan akalnya secara maksimal, termasuk orang yang rugi, karena tidak mau menjalankan peritah-Nya.

${ }^{25}$ Artinya, "Musa berkata: "Tuhan yang menguasai timur dan barat dan apa yang ada di antara keduanya: (Itulah Tuhanmu) jika kamu mempergunakan akal"." (QS. Al-Shuarā: 28).

${ }^{26}$ Artinya, “Kalau Sekiranya Kami turunkan al-Quran ini kepada sebuah gunung, pasti kamu akan melihatnya tunduk terpecah belah disebabkan ketakutannya kepada Allah. dan perumpamaan-perumpamaan itu Kami buat untuk manusia supaya mereka berfikir." (QS. AlHashr: 21).

${ }^{27}$ Berasal dari kata dasar jumūd yang berarti beku atau statis, merasa cukup dan ridho dengan apa yang Allah berikan, pemikiran dimana tidak bisa melihat sesuatu yang ada lebih luas lagi. 
penting bagi terbentuknya "Mahzab Ciputat"28. Menurut Zuly Qodir, Harun dikenal sebagai tokoh Mu'tazilah-nya Indonesia. Karena ia berkiblat kepada aliran Mu'tazilah dengan sifat Qadariahnya, yang berdasar pada peran akal dalam kehidupan. Baginya, mahzab berfikir Mu'tazilah adalah solusi bagi keterpurukan Islam, terutama Islam di Indonesia. Dalam banyak ceramahnya, Harun selalu menekankan agar kaum Muslim Indonesia berpikir secara rasional. ${ }^{29}$

Dari arah pemikirannya, dua agenda saja yang ingin Harun wujudkan, pertama; bagaimana membawa umat Islam ke arah rasionalitas, kedua; bagaimana menumbuhkan pengakuan Qadariah (akal/ pikiran) manusia. Dua hal tersebut didasarkan pada fakta umat Islam Indonesia yang cenderung ortodok $^{30}$, terkungkung oleh doktrin-doktrin agama yang tidak proporsional dan terkesan ambigu. Imbasnya, kaum Muslim Indonesia apatis dan hidup penuh pesimistis. Hemat penulis, fenomena seperti ini masih terlihat hingga sekarang. Padahal Harun sudah mewanti-wanti sejak 40 tahun lalu. Sebagaimana dikhawatirkannya, jika kejumudan dibiarkan, sikap selalu menerima dan pasrah, pesimistis, fatalistik ${ }^{31}$ terus dipelihara, justru akan berbahaya bagi umat Islam sendiri. Mereka akan semakin terisolasi dari kancah pembangunan. Harun membahasakan, "Seperti tikus mati di lumbung padi." Karena itu, agar Islam tidak mati konyol, ide positif Harun Nasution ini bisa menjadi referensi dan mewarnai ikhtiar umat Islam Indonesia ke depan.

\section{Gagasan Besar Pembaruan Islam Harun Nasution}

Dari dua agenda yang ingin Harun wajudkan kepada Islam, khususnya Islam Indonesia, setidaknya bermuara kepada tiga gagasan besarnya yaitu; peranan akal diberikan ruang yang lebih luas, pembaharuan teologi umat, dan memperbaiki hubungan akal dan wahyu.

Menurutnya, tiga hal di atas adalah hulu dari permasalahan selama ini, secara tidak tersadari, menjadi sebab kepada mundur dan lemahnya umat Islam. Islam diminta untuk kembali kepada ajaran Islam yang sebenarnya, sebagaimana diamalkan umat Islam di zaman klasik. Segala bid'ah yang

\footnotetext{
${ }^{28}$ Bermaksud menunjukkan tempat yang bernama "Ciputat", tempat IAIN Syarif Hidayatullah Jakarta berdiri, sekarang UIN Jakarta. Era 70-an hingga 90-an menjadi pusat pemikiran Islam di Indonesia. Para pemikir lainnya selain Harun Nasution ada Nurcholis Madjid, Munawir Sadjzali, Quraish Shihab. Generasi di bawahnya ada Azyumardi Azra, Komaruddin Hidayat, Said Aqiel al-Munawwar, Said Aqiel Siradj, dll.

${ }^{29}$ Zuly Qodir, Islam Liberal; Paradigma Baru Wacana dan Aksi Islam Indonesia, (Yogyakarta: Pustaka Pelajar, 2007), Cet. II, 69-73.

${ }^{30}$ Kolot, berpandangan kuno.

${ }^{31}$ Putus asa dalam segala hal. Pasrah kepada nasib.
} 
Pembaharuan Pendidikan Islam ala Harun Nasution; Sebuah refleksi akan kerinduan "keemasan islam

tidak sesuia dengan Islam dan membawa pada kemunduran dan kelemahan umat harus dibuang. Sikap taklid kepada pendapat dan penafsir lama juga harus ditinggalkan dan pintu ijtihad kembali dibuka. Yang dijadikan pegangan dan pedoman untuk mengetahui ajaran-ajaran Islam bukan lagi buku-buku karangan ulama terdahulu, tetapi hanya al-Quran dan al-Hadis. Ajaran-ajaran dasar yang ada di dalamnya disesuaikan perincian dan cara pelaksanaannya dengan perkembangan zaman. ${ }^{32}$ Dalam bahasa gampangnya, harus luwes tidak lagi kaku.

\section{A. Peranan Akal}

Berangkat dari kekagumannya kepada tokoh pembaharu Islam Muhammad Abduh, yang dikupasnya dalam kajian desertasinya di Universitas McGill, Montreal, Kanada, dengan tema "Problematika Akal Dalam Sistem Teologi Muhammad Abduh" membawanya hanyut dan terbawa metode dan misi dari tokoh idolanya itu. Selalu dikatakan bahwa besar-kecilnya peranan akal dalam sistem teologi suatu aliran sangat menentukan dinamis atau tidaknya pemahaman seseorang tentang ajaran Islam. Dijelaskan, akal melambangkan kekuatan manusia, karena akal manusia mempunyai kesanggupan untuk melakukan kekuatan mahluk lain di sekitarnya. Bertambah tinggi akal manusia, bertambah tinggi pula kesanggupannya untuk mengalahkan makhluk lain. Bertambah lemah kekuatan akal manusia, bertambah rendah pula kesanggupannya menghadapi kekuatan lain. ${ }^{33}$

Dalam ajaran Islam, akal mempuanyai kedudukan yang tinggi dan banyak digunakan, tidak hanya dalam perkembangan ilmu pengetahuan dan kebudayaan, melainkan juga dalam perkembangan ajaran-ajaran keagamaan Islam. Penggunaan akal dalam Islam diperintahkan al-Quran. Bukan tidak ada dasar bila penulis-penulis, baik dari kalangan Islam maupun non-Islam yang berpendapat bahwa Islam adalah agama rasional. ${ }^{34}$

\section{B. Pembaharuan Teologi}

Pembaharuan teologi yang menjadi gagasan Harun Nasution, pada dasarnya dibangun di atas asumsi bahwa keterbelakangan dan kemunduran umat Islam Indonesia disebabkan " ada yang salah" dalam teologi mereka. Apa yang diutarakannya ini serupa dengan pandangan

\footnotetext{
${ }^{32}$ Nasution, Pembaharuan, 207.

${ }^{33}$ Nasution dalam Abdul Rozak dan Rosihon Anwar, Ilmu Kalam, (Bandung: Pustaka Setia, 2014), Cet. III, 282.

${ }^{34}$ Ibid.
} 
kaum modernis pendahulunya seperti; Muhammad Abduh, Rashìd Riḍā, Jamaluddīn al-Afghānī, Sayyid Ahmad Khān, dan lainnya, yang memandang perlu untuk kembali pada teologi Islam yang sejati. Retorika ini mengandung pengertian bahwa umat Islam dalam teologi fatalistis, irasional, predeterminisme, ${ }^{35}$ serta penyerahan nasib telah membawa nasib mereka menuju kesengsaraan dan keterbelakangan.

Karena itu, bila serius ingin memperbaiki nasib umat Islam, menurut Harun Nasution, umat Islam segera merubah teologinya menuju teologi yang free wiil-free act (kehendak bebas-bertindak bebas), rasional, serta mandiri. Tidak heran jika teori modernisasi ini menemukan teologinya dalam khazanah Islam klasik, yaitu teologi Mu'tazilah. ${ }^{36}$ Kesimpulannya, Harun Nasution mengarahkan atau mengajak umat Islam Indonesia untuk menganut teologi Mu'tazilah. Baginya, hanya aliran ini dengan sifat Qadariahnya, yang mampu menjadikan Islam untuk kembali memegang peradaban di muka bumi. Sebagaimana Allah menurunkan manusia untuk beriman (Islam) dan menjadi khalifah guna mengelola bumi dan isinya agar bermanfaat bagi kehidupan. Ini merupakan isyarat dan perintah Allah agar akal yang sudah diciptakannya pada setiap jiwa manusia itu benar-benar difungsikan dan diberdayakan.

\section{Hubungan Akal dan Wahyu}

Fokus pemikiran Harun Nasution lainnya adalah hubungan antara akal dan wahyu. Ia menjelaskan bahwa hubungan akal dan wahyu menimbulkan pertanyaan, tetapi keduanya tidak bertentangan. Akal mempunyai kedudukan yang tinggi dalam al-Quran. Orang yang beriman tidak perlu menerima bahwa wahyu sudah mengandung segalagalanya. Wahyu tidak menjelaskan semua permasalahan keagamaan. ${ }^{37}$

Dalam pemikiran Islam, baik di bidang filsafat dan ilmu kalam, lebih-lebih di bidang ilmu fikih, akal tidak pernah membatalkan wahyu. Akal tetap tunduk pada teks wahyu. Teks wahyu tetap dianggap mutlak dan benar. Akal digunakan hanya untuk memahami teks wahyu dan tidak untuk menentang wahyu. Akal hanya memberi interpretasi terhadap teks wahyu sesuai dengan kecenderungan dan kesanggupan pemberi interpretasi. Pertentangan dalam sejarah pemikiran Islam sebenarnya bukan akal dengan wahyu, melainkan penafsiran tertentu

\footnotetext{
${ }^{35}$ Teori yang berpendapat bahwa kehendak manusia ditentukan oleh takdir, dan utamanya oleh Tuhan. Manusia tidak punya daya dan upaya.

${ }^{36}$ Mansoer Fakih dalam Suminto dalam Rozak dan Rosihon Anwar, Ilmu, 283.

${ }^{37}$ Nasution dalam Rozak dan Rosihon Anwar, Ilmu, 283.
} 
dari teks wahyu dengan penafsiran lain dari teks wahyu itu. Jadi, yang bertentangan sebenarnya dalam Islam adalah pendapat akal ulama tertentu dengan pendapat akal ulama yang lain. ${ }^{38}$

Dalam konteks ini, Harun ingin menyampaikan bahwa umat Islam jangan terjebak pada pendapat pribadi atau akal dari ulama tertentu. Hindarilah taklid buta. Carilah ulama-ulama dan pemikirpemikir Islam yang rasional dan modern, bukan ulama dan pemikir Islam yang irasional dan tradisional. Harun berharap para ulama dan pemikir Islam saat ini untuk lebih memfungsikan dan memberdayakan akalnya, terus berijtihad, pintu ijtihad terus terbuka, karena ditutupnya pintu ijtihad bersamaan dengan berakhirnya kehidupanya ini, yaitu pada hari kiamat.

Dari gagasan-gagasannya ini, Harun membuat benang merah agar dinamika di kalangan umat Islam dihidupkan kembali dengan menjauhkan faham tawakkal semata dan faham jabariyah. Umat Islam harus dibawa kembali ke teologi yang mengandung faham dinamika dan kepercayaan kepada akal dalam batas-batas yang ditentukan wahyu. Umat Islam harus dirangsang untuk berfikir dan banyak berusaha. Orientasi keakhiratan harus diimbangi dengan orientasi keduniaan, sehingga umat Islam juga mementingkan hidup kemasyarakatan dan berusaha mencapai kemajuan dalam bidang kehidupan duniawi sebagai halnya dengan umat-umat lain. ${ }^{39}$

\section{Pemikiran Pembaharuan Pendidikan Islam Harun Nasution}

Bila membaca tiga gagasan atau pemikiran pokok Harun Nasution di atas, sudah bisa dipahami esensinya. Tiga gagasan pembaharuan Islam Harun Nasution tersebut sebagai pola dasar atau fondasi yang bisa diterapkan di berbagai sektor kehidupan umat Islam kekinian, mulai dari kehidupan sosial Islam, ekonomi Islam, pendi-dikan Islam itu sendiri, bahkan politik Islam, dan lainnya. Kemer-dekaan akal, penganutan teologi yang tepat, menempatkan posisi akal sesuai kebutuhannya di antara wahyu, adalah dasar dari pola-pola kehidupan tersebut.

Misalkan dalam kehidupan politik, Harun menyarankan agar pemerintahan absolut dirubah dan ditukar kembali dengan pemerintahan demokrasi. Ke dalam dunia Islam harus dimasukkan sistem pemerintahan konstitusional. Dengan demikian, umat akan turut memikirkan problemaproblema yang dihadapi negaranya dan ikut mencari solusi atau cara

\footnotetext{
${ }^{38}$ Ibid.

${ }^{39}$ Nasution, Pembaharuan, 207-208.
} 
penyelesaiaannya. Turut berusaha dan turut bertanggung jawab atas usahausaha untuk mencapai kemajuan dan kemandirian. ${ }^{40}$

Lantas bagaimana penerapannya dalam pendidikan Islam. Harun dengan gamblang mengutarakan untuk merobah pola pendidikan Islam tradisional ke arah yang pendidikan Islam yang modern. Dengan memasukkan mata pelajaran tentang ilmu-ilmu pengetahuan modern ke dalam kurikulum sekolah Islam atau madrasah-madrasah. Harun juga meminta kepada para pemangku kebijakan dan pemikir Islam, untuk mendirikan sekolah-sekolah Islam atau madrasah modern di samping madrasah-madrasah yang telah ada, sebagai madrasah percontohan. Dengan ini diharapkan, muncul-muncul ahli-ahli Islam dalam bidang Iptek. Mereka inilah yang akan membawa umat kepada kemajuan dalam kehidupan duniawi. ${ }^{41}$

Sebagai seorang dosen, Harun Nasution, selain memperhatikan pendidikan di tingkatan madrasah untuk menemukan bibit-bibit unggul intelektual Islam, sangat berharap kepada perguruan-perguruan tinggi Islam (Saat itu STAIN dan IAIN, kini sudah berdiri $23 \mathrm{UIN}^{42}$ ), serta perguruanperguruan tinggi Islam swasta ${ }^{43}$ lainnya di seluruh Indonesia, untuk menjadi pelopor munculnya pembaharu-pembaharu Islam. Inti dari ide pembaruan Harun Nasution di perguruan tinggi Islam adalah pola sistem pembelajaran yang terbuka dan demokratis. Salah satu motode Harun yang nampak adalah merubah cara mengajar mahasiswanya, bila yang lain menggunakan metode ceramah, ia menggantinya dengan motode presentasi dan diskusi. Budaya menulis mahasiswa dikembangkan dengan memberinya tugas membuat makalah. Hal ini ia lakukan untuk melatih pola berpikir mahasiswa lebih sistematis dan kritis, diberi kebebasan berfikir sekaligus menga-nalisis persoalan dan problema-problema secara leluasa.

Mau tidak mau, isu Demokrasi merupakan warna lain yang mempengaruhi masa depan pendidikan Islam di Indonesia. Tuntutan demokratisasi pada awalnya ditujukan pada sistem politik negara sebagai "perlawanan" terhadap sistem politik yang otoriter. Dalam perkembangan-

\footnotetext{
${ }^{40}$ Ibid., 208.

${ }^{41}$ Ibid.

${ }^{42}$ IAIN yang sudah transformasi ke UIN antara lain: UIN Alaudin Makasar, UIN Ar-Raniry Banda Aceh, UIN Maulana Malik Ibrahim Malang, UIN Raden Fatah Palembang, UIN Sultah Syarif Kasim Pekanbaru, UIN Sumeta Utara, UIN Sunam Ampel Surrabaya, UIN Sunan Gunung Djati Bandung, UIN Sunan Kalijaga Yogyakarta, UIN Syarif Hidayatullaj Jakarta, dan UIN Wali Songo Semarang. Sedangkan IAIN berjumlah 23, dan STAIN berjumlah 19.

${ }^{43}$ Saat ini telah berdiri ratusan perguruan tinggi Islam swasta di seluruh Indonesia, baik yang berada di bawah naungan Kementerian Agama maupun yang berada di bawah naungan Kementerian Riset, Teknologi dan Pendidikan Tinggi.
} 
nya, tuntutan ini mengarah pada sistem pengelolaan berbagai bidang kehidupan, sebagaimana sudah disinggung di atas, termasuk bidang pendidikan. Bila sebelumnya sistem pendidikan bersifat sentralistik, seragam, dependen dan beku, kini berkembang tuntutan pengelolaan pendidikan yang lebih otonom, terbuka dan beragam. Tuntutan demokratisasi pendidikan ini menggeser paradigma pendidikan Islam untuk lebih menekankan pada peran aktif peserta didik. ${ }^{44}$ Muaranya, agar perkembangan mereka ke depan bisa memiliki pola pikir yang modern.

Sebagaimana diutarakan juniornya, Azyumardi Azra, Harun Nasution saat menjabat Rektor IAIN Syarif Hidatullah Jakarta, menja dikan lembaga tersebut berada pada garis depan gerakan pembaharuan di IAIN secera keseluruhan. Harun bercita-cita menjadikan IAIN Jakarta sebagai pusat modernisasi umat Islam. Langkah konkrit yang dilakukannya adalah merestrukrisasi kurikulum IAIN secara menyeluruh. ${ }^{45}$ Ia memperkenalkan beberapa matakuliah yang selama ini tidak atau kurang dikenal di lingkungan IAIN, seperti filsafat Islam, teologi Islam, tasawuf dan aliranaliran modern dalam Islam. Dari segi metodologis, berbagai ilmu yang dipelajari di IAIN juga mulai didekati secara lebih objektif, dan nonpartisan. Mahasiswa dituntut mencoba memahami perbedaan pandangan di antara berbagai mazhab dan aliran sesuai dengan sudut pandang mazhab atau aliran masing-masing. ${ }^{46}$

Pembaharuan kurikulum yang diperkenalkan Harun Nasution ini, telah membuka cara pandang dan arah baru kajian Islam di lingkungan IAIN. Pendekatan dan metodologi yang ditawarkan Harun Nasution, yang kemudian dikenal sebagai pendekatan "non-mazhabi", selanjutnya menjadi ciri sebagian besar alumni IAIN Jakarta, khususnya para lulusan sejak paruh kedua 1970-an. Hasilnya adalah, kemunculan sejumlah alumni, sejak dalam 1980-an, yang bergerak di luar sektor pemerintahan, dan mempunyai pengaruh yang signifikan dalam penyebaran dan pengembangan gagasan pembaharuan Islam. ${ }^{47}$ Pada saat yang sama, banyak alumni IAIN Jakarta bergerak dalam birokrasi turut menjadi motor dalam pembaharuan kelembagaan Islam. ${ }^{48}$

\footnotetext{
${ }^{44}$ Husni Rahim, Arah Baru Pendidikan Islam Indonesia, (Jakarta: Logos Wacana Ilmu, 2001), 15.

${ }^{45}$ Azyumardi Azra, Pendidikan Islam; Tradisi Modernisasi Di Tengah Tantangan Milenium III, (Jakarta: Kencana Prenada Meia Group, 2012), 215.

${ }^{46}$ Baseline Study dalam Saiful Mujani dalam Azra, Pendidikan, 215.

${ }^{47}$ Terutama para cendekiawan Muslim yang berada pada lingkaran "Mazhab Ciputat". Azra, Pendidikan, 215.

${ }^{48}$ Baseline dalam Azra, Pendidikan, 215.
} 
Selanjutnya, setelah kita ulas ide pembaruan pendidikan Islam yang ditawarkan Harun Nasution, mari kita lihat seperti apa perkembangan pendikan Islam di Indonesia saat ini. Secara eksplisit tawaran-tawaran Harun terkait pembaharuan pendidikan Islam telah nampak sejak Harun mengemukan ide-idenya hingga sekarang. Kita amati sekarang, madrasahmadrasah dari tingkat dasar hingga menengah sudah membuka diri. Segala yang berbau Iptek dipersilakan masuk dan dipelajari para siswa. Madrasahmadrasah unggulan, baik negeri maupun swasta, mulai bermunculan dan bersaing. Selain bersaing pada level setara madrasah, juga berkompetisi secara objektif dengan sekolah-sekolah umum. Mereka bersaing mulai dari prestasi murid, prestasi guru, hingga prestasi kelembagaan, baik di bidang akademik dan non-akademik.

Untuk tingkat perguruan tinggi Islam, ide Harun Nasution juga sudah tercover dan terus berlangsung hingga saat ini. Misalnya, dengan adanya gerakan transformasi dari IAIN ke UIN merupakan upaya meningkatkan rasionalisme dan keterbukaan pada pendidikan Islam itu sendiri secara khusus, dan umat Islam Indonesia bahkan dunia secara umum. Menurut Amin Abdullah, transformasi, pengem bangan dan konversi IAIN ke UIN adalah proyek keilmuan. Proyek pengembangan wawasan keilmuan dan perubahan tata pikir keilmuan yang bernafaskan keagamaan transformatif. Konversi dari IAIN ke UIN merupakan momentum untuk membenahi dan menyembuhkan "luka-luka dikotomi" keilmuan umum dan agama. Langkah ini mengandung arti perlunya dialog dan kerja sama antara disiplin ilmu umum dan agama yang lebih erat di masa yang akan datang. ${ }^{49}$ Terobosan ini dalam rangka menempatkan posisi akal pada porsinya, sebagaimana yang dimaui Harun Nasution. Semangat tranformasi di kampus Islam negeri ini, dengan mensejajarkan antara ilmu pengetahuan agama dengan ilmu pengetahuan umum (untuk saling melengkapi) setidaknya juga dilakukan pada kampus-kampus Islam swasta, mengingat dari segi kuantitas jumlah kampus Islam swasta jauh lebih banyak dari jumlah kampus Islam negeri.

Kini, pola pembelajaran di perguruan tinggi Islam semuanya sudah serba terbuka. Budaya diskusi, tulis-menulis, kebebasan berpikir bahkan kebebasan bergerak (berekpresi) yang masih dalam koridor keislaman, telah digalakkan di semua perguruan tinggi Islam, mulai dari STAIN, IAIN, UIN dan perguruan tinggi Islam swasta. Namun, saat ini belum terlihat secara nyata produk pembaharuan keilmuan tersebut. Buktinya, kiblat keilmuan (Iptek) hingga detik ini masih berada di Barat. Belum tahun kapan kiblat

\footnotetext{
${ }^{49}$ Amin Abdullah, dkk., Islamic Studies; Dalam Paradigma Integrasi-Interkoneksi , (Yogyakarta: Suka Press, 2007), 33.
} 
Pembaharuan Pendidikan Islam ala Harun Nasution; Sebuah refleksi akan kerinduan "keemasan islam

keilmuan kembali kita raih. Para pemikir Islam, tidak hanya di Indonesia, termasuk pemikir-pemikir Islam dunia, menyadari akan berat dan sulitnya merebut kembali peradaban dunia yang sudah terlepas, yang pernah kita kuasi di zaman "Islam Glory" (keemasan Islam) dulu.

Bila dari segi kuantitas, para sarjana Muslim tidak kalah dengan para sarjana Barat. Pemikir Muslim tidak kalah dengan Pemikir Barat. Ambil contoh di Indonesia, ribuan madrasah dari tingkat bawah hingga tingkat atas tersebar di seluruh Indonesia, baik berstatus negeri maupun swasta. Semua keilmuan diajarakan di sana, baik ilmu agama dan ilmu umum (Iptek). Ratusan perguruan tinggi Islam, baik negeri dan swasta, juga tersebar di seluruh tanah air, dengan puluhan ribu sarjananya, mulai S1 hingga Profesor. ${ }^{51}$ Dengan melihat data tersebut, menjadi kebanggaan, namun bila ditarik kepada zaman keemasan Islam, menjadi sebuah kepiluan. Menurut penulis, kualitas para kaum terdidik dan pemikir Islam ini yang menjadi pekerjaan rumah kita. Untuk tidak kalah berkualitasnya dengan para kaum terdidik dan pemikir Barat, yang notabene nenek moyang mereka dulu belajar kepada nenek moyang kita, nenek moyang umat Islam sekarang. Inilah yang menjadi problema baru kita. Mari kita-kita sama mencari jalan keluarnya.

Setidaknya, gagasan dari Siswanto bisa menyumbangkan sedikit solusi, di mana menurutnya, kuatnya pergumulan Islam dan Barat telah menggugah dan membawa perubahan paradigmatif umat Islam untuk belajar kepada Barat, sehingga ketertinggalan dalam beberapa prinsip keilmuan bisa diminimalisir. ${ }^{52}$ Di sini mengisyaratkan bahwa mau tidak mau, percaya tidak percaya, kita harus mengakui bahwa sekarang Barat yang memegang peradaban dunia, khususnya dalam bidang kemajuan Iptek. Islam masih "bodoh" dan kurang mumpuni bila berbicara pada bidang tersebut. Maka hilangkan rasa gengsi, meski dulu peradaban itu pernah kita kuasai, berbondong-bondonglah Islam belajar ke Barat agar tidak semakin tertinggal dan terpuruk. Mungkin itulah refleksi akhir dalam tulisan yang singkat ini.

\section{Epilog}

Inti dari artikel ini, mencoba untuk mengingatkan kembali akan semangat pembaharuan Islam yang diutarakan oleh Harun Nasution.

\footnotetext{
${ }^{50}$ Meminjam istilah Bung Karno saat berpidato di depan para sarjana Muslim Indonesia dan umat Islam Indonesia lainnya, di Jakarta, awal tahun 60-an.

${ }^{51}$ Zuhairini, dkk., Sejarah Pendidikan Islam, (Jakarta: Bumi Aksara, 2006), Ed. I, Cet. VIII, 209-237.

${ }^{52}$ Siswanto, Dinamika Pendidikan Islam Pesrspektif Historis, (Surabaya: Pena Salsabila, 2013), 113.
} 
Pembaharuan Pendidikan Islam ala Harun Nasution; Sebuah refleksi akan kerinduan "keemasan islam

Sebenarnya tujuan dari gagasannya tersebut demi majunya Islam di masa depan. Bila Islam hanya berdiam diri dan pasrah, maka sampai akhir kehidupan ini peradaban dan keilmuan Islam akan mandeg dan mati. Harun pribadi merasa miris dan tidak terima bila Islam di masa depan akan menjadi seperti itu. Harun mengajak umat Islam untuk mentrasfer kembali semangat kejayaan Islam di masa lalu, khususnya kejayaan di bidang ilmu pengetahuan.

Keinginan Harun, khususnya untuk umat Islam Indonesia hanya dua yaitu, pertama; bagaimana membawa umat Islam ke arah rasionalitas, kedua; bagaimana menumbuhkan pengakuan akal dan pikiran manusia. Dari dua keinginannya itu, Harun sangat berharap kepada lembaga-lembaga pendidikan Islam, terutama perguruan-perguruan tinggi Islam untuk bisa mewujudkannya. Kemerdekaan akal, penganutan teologi yang tepat, menempatkan posisi akal sesuai kebutuhannya di antara wahyu, adalah dasar dari pola-pola pendidikan Islam yang harus dijalani.

Harun mengajak untuk merobah pola pendidikan Islam tradisional ke arah pendidikan Islam yang modern. Dengan memasuk-kan mata pelajaran tentang ilmu-ilmu pengetahuan modern ke dalam kurikulum sekolah Islam atau madrasah-madrasah, termasuk juga perguruan tinggi Islam. Pola pembelajaran di perguruan tinggi Islam untuk lebih terbuka dan demokratis. Budaya diskusi, tulis-menulis, kebebasan berpikir bahkan kebebasan bergerak (berekpresi) yang masih dalam koridor keislaman, untuk digalakkan di semua perguruan tinggi Islam, baik negeri maupun swasta. Hal ini untuk melatih pola berpikir mahasiswa lebih sistematis dan kritis, diberi kebebasasn berfikir sekaligus menganalisis persoalan dan problemaproblema secara leluasa, serta dapat menemukan solusinya.

\section{Daftar Pustaka}

Abdullah, Amin, dkk. Islamic Studies; Dalam Paradigma IntegrasiInterkoneksi. (Yogyakarta: Suka Press, 2007).

Azra, Azyumardi. Pendidikan Islam; Tradisi Modernisasi Di Tengah Tantangan Milenium III. (Jakarta: Kencana Prenada Media Group, 2012).

Daulay, Haidar Putra. Sejarah Pertumbuhan dan Pembaharuan Pendidikan Islam Di Indonesia. (Jakarta: Prenada Media Group, 2014). Cet. IV.

Halim, Abdul. Teologi Islam Rasional; Apreriasi Terhadap Wacana dan Praksis Harun Nasution. (Jakarta: Ciputat Press, 2001).

Nasution, Harun. Islam Rasional. (Bandung: Mizan, 1995).

-Pembaharuan Dalam Islam; Sejarah Pemikiran dan Gerakan. (Jakarta: Bulan Bintang, 1992). Cet. IX. 
Pembaharuan Pendidikan Islam ala Harun Nasution; Sebuah refleksi akan kerinduan "keemasan islam

---------Teologi Islam; Aliran-aliran Sejarah Analisa Perbandingan. (Jakarta: UI-Press, 1986). Cet. V.

Nata, Abuddin. Metodologi Studi Islam. (Jakarta: Raja Grafindo Persada, 2014).

---------Peta Keragaman Pemikiran Islam Di Indonesia. (Jakarta: Raja Grafindo Persana, 2001).

Qodir, Zuly. Islam Liberal; Paradigma Baru Wacana dan Aksi Islam Indonesia. (Yogyakarta: Pustaka Pelajar, 2014). Cet. II.

---------Islam Liberal; Varian-varian Liberalisme Islam Di Indonesia 19912002. (Yogyakarta: tp, 2012).

Rahim, Husni. Arah Baru Pendidikan Islam Indonesia. (Jakarta: Logos Wacana Ilmu, 2001).

Rozak, Abdul dan Rosihon Anwar. Ilmu Kalam. (Bandung: Pustaka Setia, 2014). Cet. III.

Siswanto. Dinamika Pendidikan Islam Perspektif Historis. (Surabaya: Pena Salsabila, 2013)

Zuhairini, dkk. Sejarah Pendidikan Islam. (Jakarta: Bumi Aksara, 2006). Ed. I. Cet. VIII. 